\title{
病院前救急診療活動を行う医阬の活動中の感情と 普段の精神的健康状態との関連
}

\author{
市村 美帆 ${ }^{1}$ 高田 治樹 ${ }^{2}$ 増野 智彦 ${ }^{3}$ 吉野 美緒 ${ }^{4}$ \\ 稲本 絵里 ${ }^{5}$ 松 井 豊 ${ }^{2}$ 横田 裕行 $^{3}$
}

\begin{abstract}
要旨 本研究の目的は, 病院前救急診療活動（Doctor Ambulance: DA または Doctor Helicopter: DH による活動，以下 $\mathrm{DA} / \mathrm{DH}$ 活動とする）を取り上げ， DA/DH活動に伴う心理状態の実態を把握す ることである。加えて, 活動に伴う経験が DA/DH活動者の精神的健康に与える影響についても

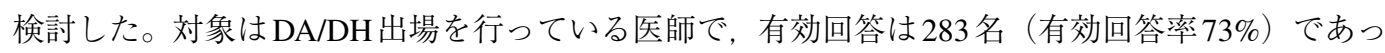
た。質問紙調査において, 普段の活動前・活動中 ・活動後に感じていることや行っていること, 精神的健康（The General Health Questionnaire; GHQ）の高さを測定した。その結果，DA/DH活動 者は, 活動の使命感を感じていながらも，活動前や活動中に現場や患者の状況がわからず，自身 の能力を超えているかもしれないという不安を感じていることが明らかになった。活動後には, ともに出場した人や同僚と会話をすることによって，活動中の経験や感情の共有をしていた。ま た DA/DH活動者のうち全体の $24.4 \%$ が精神的不健康の高リスク群であることが明らかになった。 高リスク群は，活動前に自分の能力を超えているかもしれない，批判を受けるかもしれないとい う不安を感じ, 活動中には無力感や怒りなどを感じていた。DA/DH活動者のなかには, 活動に よって心的負担を感じ，精神的不健康に陥っている者が存在することが明らかになった。本研究 の結果を踏まえると, DA/DH活動の活動支援システムとして, 活動者が活動時に経験する不安 や恐怖に焦点をあてた事前教育および訓練と，それらに対処するための組織的な取り組みが必要 である。
\end{abstract}

（日救急医会誌. 2014; 25: 141-51）

キーワード：ドクターカー, ドクターヘリ, 精神的不健康, 事前教育

\section{背景と目的}

病院前救急診療活動（Doctor Ambulance: DAまた は Doctor Helicopter: DHによる医療救援活動, 以下 DA/DH活動とする）は近年ますます盛んになり，そ

The relation between psychological conditions and mental health on the physicians working in prehospital care

${ }^{1}$ 目白大学人間学部

2 筑波大学大学院人間総合科学研究科

3 日本医科大学付属病院高度救急センター

${ }^{4}$ 日本医科大学付属病院小児科

${ }^{5}$ 日本医科大学多摩永山病院

著者連絡先：干161-8539 東京都新宿区中落合 4-31-1

原稿受理日：2013年5月 8 日（13-042）
の有用性も広く認識されるようになっている。DA/ DH 活動は, 救急患者発生からより短時間で初期治 療を開始することを目的としており，限定的な情報 のもとで出場し, 必要最低限の医療器材で活動する ことが求められる ${ }^{1)}$ 。加えて, DA/DH活動は, 急病 患者に対する活動だけではなく, 事件および事故, 災害現場などへも出場するなど，その活動内容は多 岐にわたり，活動現場の状況は予測困難であること も多い。

またDA/DH活動現場において迅速かつ的確な診 療活動をするためには，活動前や活動中に警察官や 救急隊員などと情報を共有し, 協働して活動する必 要がある。加えて, 活動現場には協働者だけではな 
く，患者の家族や衆人，時にはマスメディアなどが いることもあり，多くの人が傍観している前での活 動を余儀なくされることもある。

さらに予測困難な現場では, 自身が様々な危険に 遭遇する可能性もある。たとえば，活動者が凄惨な 現場を目撃したり，活動者自身が身の危険を感じる などの経験をすることも予想される。時には DA/DH 活動者が, 患者の家族や衆人, マスメディアから批 判されることもあると考えられる。

以上のように，DA/DH活動は，限られた情報と 人的・物的資源を活用し, 短時間に様々な人と接触 しながら診療活動を行うという点, 予測困難な現場 では時として自身が危険にさらされる可能性をもつ 点など, 通常診療とは異なる特徵をもつことから， 活動によって心的負担を感じ, 精神的健康を維持す ることができない状態に陥る危険性も考えられる。

しかし，DA/DH活動に伴う活動者の心理状態の実 態については明らかにされていない。またそれらの 経験が DA/DH 活動者の精神的健康に与える影響に ついても検討されていない。そのため, 活動者自身 がDA/DH活動によってどのようなリスクを負うこ とがあるのかを十分に理解していない可能性さえあ り, 活動者に対する精神的支援システムが十分に構 築されていないのが現状である。

そこで本研究は, DA/DH活動に伴う心理状態の 実態を把握することを目的とする。具体的には， DA/DH 活動者に普段の活動前や活動中に感じてい ることや, 活動後に行っていることを尋ね, 活動に 伴う心理状態の実態を把握する。加えて，それらの 経験がDA/DH 活動者の精神的健康にどのような影 響を与えているのか検討する。以上の結果を踏ま え, DA/DH活動者を対象とした活動支援システム のあり方について議論する。

\section{対象と方法}

\section{1. 調査対象者}

調査実施前に, 国内（沖縄を除く）において，DA/ DH出場を行っている医療機関に対して, 研究目的を
説明し，協力を要請した。協力が得られ，かつ年間 出場数が 50 件以上の医療機関に勤務する医師 388 名 を対象に調査を実施した。

\section{2. 調査期間}

2010年9月〜 10 月であった。

\section{3. 調査方法}

調査用紙は，協力依頼状や返信用封筒とともに協 力の得られた医療機関に勤務する医師に個別に配布 された。回答者のプライバシーを保護するために, 回答は無記名形式で行われ, 対象者は調査用紙の回 答後に返信用封筒に入れ，集計機関に郵送した。

なお質問項目には，精神的健康に関する項目など が含まれていることから，回答者が不調を来す可能 性を考慮し, 臨床心理士による相談体勢を整え, 配 布した協力依頼状に相談先を記載した。ただし実際 の相談はなかった。

\section{4. 調査項目}

（1）普段の活動に関する項目：出場頻度, 出場形態 について単一回答方式で尋ねた。

（2）普段活動前に感じることに関する項目：活動前 に感じることとして 10 項目を作成し，自身にあ てはまるものについて複数回答方式で尋ねた。

（3）普段活動中に感じることに関する項目：活動中 の感情として14項目を作成し，自身にあては まるものについて複数回答方式で尋ねた。

（4）普段活動後に行っていることに関する項目：活 動後の行動として7項目を作成し，自身にあて はまるものについて複数回答方式で尋ねた。

（5）GHQ-12：成田 ${ }^{2)}$ が選定した 12項目を用いて4 件法で回答を求めた。GHQ（The General Health Questionnaire) は, 非器質性, 非精神病性の精 神障害をスクリーニングすることを目的として, Goldberg ${ }^{3)}$ によって作成された心理検査である。

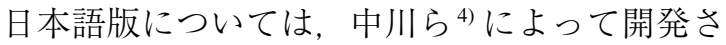
れている。GHQの項目は, 主として, 抑うつ 
的であること，不安を高く感じていること，社 会的活動が困難になっていること, 身体が不調 であることなどの特徴を基に作成されており， GHQの得点が高いほど精神的不健康であるこ とを示す。またカットオフポイント（4点以上） によって, 精神的不健康の危険性が高い高リス ク群を抽出することが可能である。高リスク群 は抑うつ的であり，不安を高く感じており， 常生活における様々な活動が困難となっていた り，気分がすぐれなかったり，身体が不調と なっているものと捉えることができる。

なお $\mathrm{GHQ}$ のオリジナル版は 60 項目から構成 されているが，近年短縮版が開発されている。 本研究で使用する 12 項目版については, 一般 成人を対象とした無作為抽出による調査を行っ た研究 (5)にいて，十分な信頼性をもつことが 確認されている。加えて, 因子構造や得点分布, 回答者の属性による差異についても概ね先行研 究と同様の知見が得られていることから, 精神 的健康を測定する項目として有用であると判断 した。また教示文において，最近2-3 週間の健 康状態を尋ねており，普段の精神的健康を捉え る尺度として採用した。

（6）属性項目：性別 - 年代 ·役職・医療に携わって いる年数, 救急医療に携わっている年数, 配偶 者有無, 子有無について単一回答方式で尋ねた。

\section{5. 解析方法}

はじめに調査項目 (1)-(4)，（6）の各項目への選択 率を基にDA/DH活動の実態を捉えた。調査項目 (5) の GHQ-12の各項目への回答に対し, GHQ方式（00-1-1方式）にて得点を算出し, 各対象者の精神的 不健康を示す得点（GHQ得点）とした。GHQ得点 については，以下の2つの検定を行った。第 1 に, 属性項目, 普段の活動の出場頻度や出場形態によっ て，GHQ得点の高さが異なるかどうか検討するため にt検定および1要因の分散分析を行った。第2に, GHQ得点のカットオフポイントである 4 点以上を精
神的不健康の危険性がある高リスク群とし，高リス ク群の特徴を検討するために, GHQリスク群（高リ スク群・低リスク群）と，普段活動前に感じること に関する項目および活動中の感情項目, 活動後の行 動項目（肯定・非肯定）について $\chi^{2}$ 検定を行った。 データの処理や解析については, Microsoft社のExcel とSPSS社のSPSSを用いた。

\section{結果}

\section{1. 回答者の属性}

本調査の有効回答者数は, 283 名であった（有効 回答率73\%)。回答者の属性についてはTable 1 に示 す。

\section{2. 普段の活動の実態}

普段の活動の出場頻度については, 月に 11 回以上 が4.9\%，月に6-10回が $18.7 \%$ ，月に1-5 回が59.7\%， 半年に数回が $14.1 \%$ ，年に 1 回以下が $1.4 \%$ であった。 出場形態については，DAでの活動が $43.1 \%$ であり, DHでの活動が43.5\%，DAおよびDHの両方での活動 が13.4\%であった。また普段の活動地域については, 主に都市部が $31.8 \%$ ，主に非都市部が30.4\%，都市部

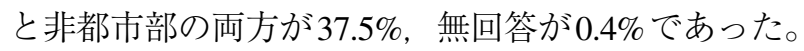
普段活動前に感じることや活動中の感情，および 活動後の行動の回答を, Fig. 1-3に示す。活動前に感じ ることについては，「どんな現場か気になる $(58.3 \%) 」$

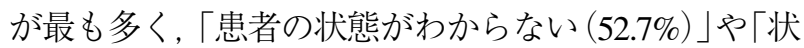
況が自分の能力を超えているかもしれない（51.9\%)」,

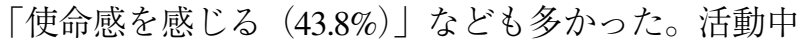
の感情については,「使命感 $(60.1 \%) 」 か ゙$ 最も多く,「高

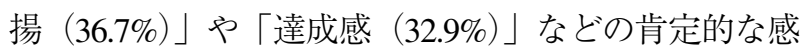
情を感じていた。一方で，「焦り (24.0\%)」や「恐怖 (16.3\%)」などの否定的な感情を感じている者もいた。 活動後の行動は,「共に出場した人と活動内容につ いて話をする $(72.8 \%) 」 や 「$ 同僚に活動内容を話す

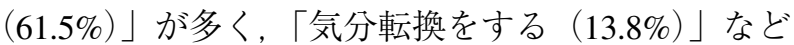
もみられた。

次に救急医療に携わっている年数による普段の活 
Table 1. Characteristics of subjects.

\begin{tabular}{|c|c|c|}
\hline & & $\mathrm{n} \quad(\%)$ \\
\hline \multirow[t]{3}{*}{ Gender } & Male & $245(86.6)$ \\
\hline & Female & $37(13.1)$ \\
\hline & No Answer & $1 \quad(0.4)$ \\
\hline \multirow[t]{4}{*}{ Age } & In the $20 \mathrm{~s}$ & 47 (16.6) \\
\hline & In the $30 \mathrm{~s}$ & $134(47.3)$ \\
\hline & In the $40 \mathrm{~s}$ & $72(25.4)$ \\
\hline & 50 or more & $30(10.6)$ \\
\hline \multirow[t]{5}{*}{ Position } & Physician-in training (first, second year) & $9 \quad(3.2)$ \\
\hline & Physician-in training (third, fourth year) & 47 (16.6) \\
\hline & Rotated from another departments & $4 \quad(1.4)$ \\
\hline & Staff & $217(76.7)$ \\
\hline & Others & $6 \quad(2.1)$ \\
\hline \multirow[t]{6}{*}{ Medical experience } & $0-5$ years & $59(20.8)$ \\
\hline & $6-10$ years & 79 (27.9) \\
\hline & $11-15$ years & $59(20.8)$ \\
\hline & $16-20$ years & $38(13.4)$ \\
\hline & Within 21 years & $47(16.6)$ \\
\hline & No answer & $1 \quad(0.4)$ \\
\hline \multirow[t]{5}{*}{ Experience in emergency medicine } & $0-5$ years & $119(42.0)$ \\
\hline & $6-10$ years & $70(24.7)$ \\
\hline & $11-15$ years & 41 (14.5) \\
\hline & $16-20$ years & $29(10.2)$ \\
\hline & Within 21 years & $24 \quad(8.5)$ \\
\hline \multirow[t]{3}{*}{ Mainly taken areas } & Mainly urban areas & 87 (31.3) \\
\hline & Mainly rural areas & 85 (30.6) \\
\hline & Both urban and rural areas & $106(38.1)$ \\
\hline \multirow[t]{2}{*}{ Marital status } & Married & $202(71.4)$ \\
\hline & Unmarried & 81 (28.6) \\
\hline \multirow[t]{2}{*}{ Children } & Yes & $165(58.3)$ \\
\hline & No & 118 (41.7) \\
\hline
\end{tabular}

Worry about situation of the scene

Unsure of conditions of the patient

Anxiety about ability to deal with the conditions

Sense of duty

Fear of danger

Unsure of surrounding conditions

Highly motivated

Worry about criticism

Feel nothing

Others

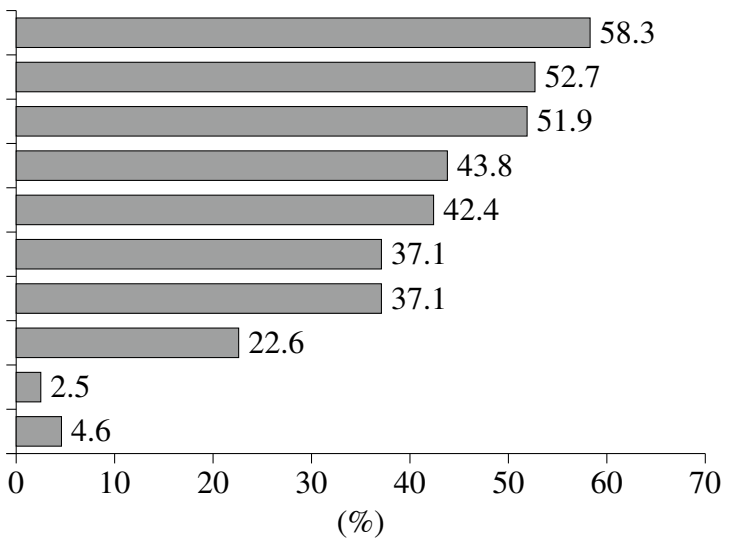

Fig. 1. Selected pre-operation feelings.

This question is multiple answer. 


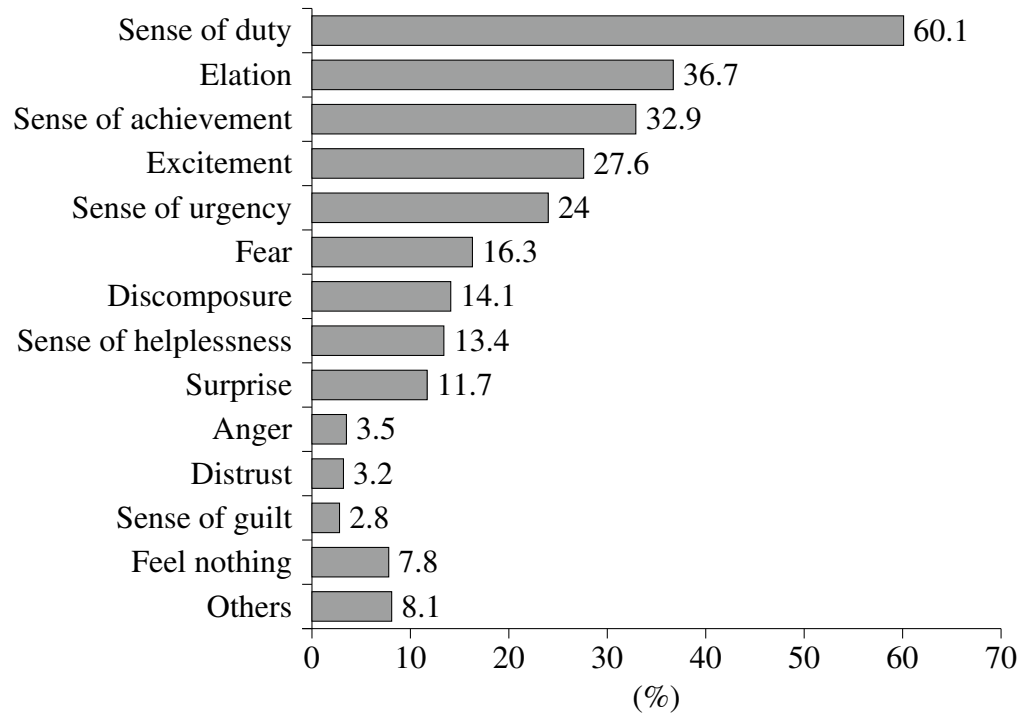

Fig. 2. Selected feelings experienced during the operation.

This question is multiple answer.

Talking with people that participated in the activities about the activity content

Talking to colleagues about the content of activity

Talking or reporting the content of activity to the supervisors

Sharing the feelings with people that participated in the activities together

Changing mood

Doing nothing

Others

13.8

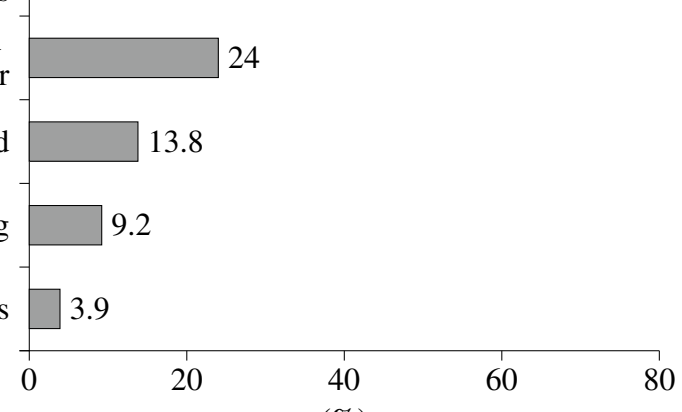

61.5

24

39.9

$(\%)$

Fig. 3. Selected post-operation activities.

This question is multiple answer.

動前に感じることや活動中の感情の選択率の相違を 検討するために, クロス集計表を作成し $\chi^{2}$ 検定を実 施した。その結果, 普段活動前に「状況が自分の能 力を超えているかもしれない」を選択した者は「0-5 年」 $(55.1 \%)$ で有意に多く,「6-10年」(18.4\%) と「16 年 -20 年」 $(6.1 \%)$ で有意に少なかった $\left(\chi^{2}=23.36\right.$, $\mathrm{p}<0.001)$ 。活動中に「怒り」を選択した者は, 「0-5 年」 (10.0\%) で有意に少なく,「16-20年」(40.0\%) で有意
に多かった $\left(\chi^{2}=13.14, \mathrm{p}<0.05\right)$ 。「恐怖」を選択した 者は, 「0-5年」 (60.9\%) で有意に多かった $\left(\chi^{2}=11.19\right.$, $\mathrm{p}<0.05)$ 。

\section{DA/DH 活動者の精神的不健康の高さ}

精神的不健康の高さを示す GHQ-12について，GHQ 方式（0-0-1-1 方式）にて得点を算出したところ, 平均 $=2.25, \mathrm{SD}=2.57$ であり, 得点範囲は0-12であった。高 


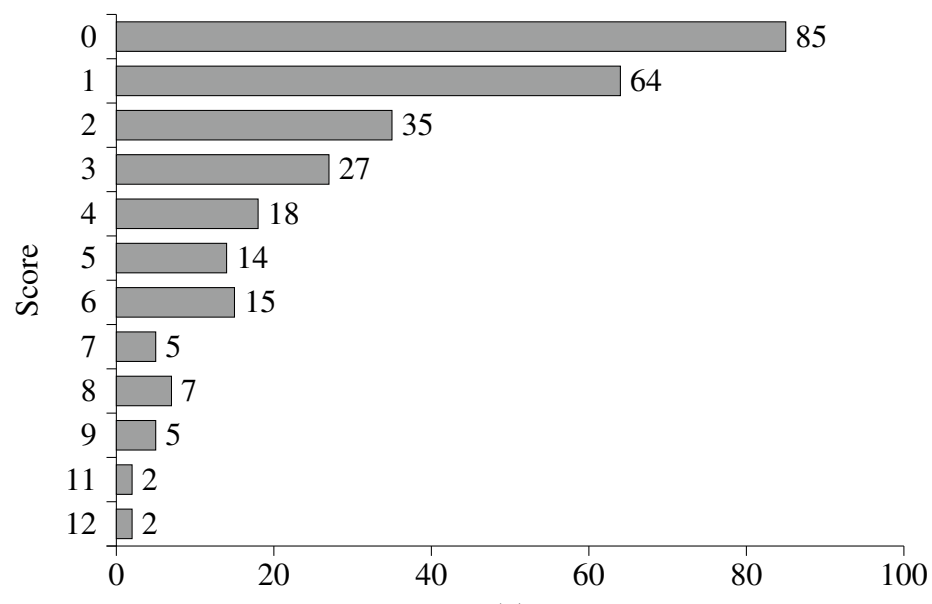

(n)

Fig. 4. GHQ score.

The scores were calculated by the GHQ method (Mean=2.25, SD=2.57, range $=0-12$ ). Cut-off point was 4 or more points. The GHQ indicated that $24.4 \%(\mathrm{~N}=68)$ of the participants were at high risks of mental health problems.

リスク群 (4点以上) は68名 $(24.4 \%)$ であった（Fig.4）。 属性項目および出場頻度, 出場形態などの回答別 に GHQの得点を比較するためにt検定もしくは1要因 の分散分析を行った。その結果, 配偶者の有無のみ 有意な差があり $(\mathrm{t}(122)=2.55, \mathrm{p}<0.05)$ ，配偶者がいる 者 $(\mathrm{n}=199)$ よりも, いない者 $(\mathrm{n}=80)$ の方が $\mathrm{GHQ}$ の 得点が高かった。他の属性項目については，有意な 差がみられなかった。同様に, 出場頻度, 出場形態 別にGHQの得点を比較したところ, 全ての項目にお いて有意な差がみられなかった（Table 2)。

\section{4. 精神的不健康の高リスク群の活動に関わる特徵}

$\mathrm{GHQ}$ の高リスク群の特徵を検討するために, GHQ リスク群（高リスク群・低リスク群）と, 普段活動 前に感じることに関する項目および活動中の感情項 目，活動後の行動項目（肯定・非肯定）について $\chi^{2}$ 検定を行った（Table 3)。その結果, GHQの高リス ク群は, 普段活動前に「状況が自分の能力を超えて いるかもしれない」（ $\left.\chi^{2}=16.20, \mathrm{p}<0.01\right)$ や「批判を 受けるかもしれない」 $\left(\chi^{2}=8.89, \mathrm{p}<0.05\right)$ と感じてい る者が有意に多かった。また GHQの高リスク群は， 活動中に「無力感」 $\left(\chi^{2}=15.40, \mathrm{p}<0.01\right)$ や「恐怖」 $\left(\chi^{2}=6.33, \mathrm{p}<0.05\right), \quad \Gamma$ 動摇」 $\left(\chi^{2}=16.35, \mathrm{p}<0.01\right), \quad\lceil$ 罪
悪感」 $\left(\chi^{2}=11.32, \mathrm{p}<0.01\right),\left\lceil\right.$ 焦り」 $\left(\chi^{2}=5.62, \mathrm{p}<0.05\right)$ などを感じている者が有意に多かった。また $\mathrm{GHQ}$ の高リスク群は，普段活動後に「気分転換をする」 $\left(\chi^{2}=4.81, \mathrm{p}<0.05\right)$ 者が有意に多かった。

\section{考察}

本研究では, DA/DH活動に伴う心理状態の実態 を把握することを目的とし, 普段の活動前や活動中 に感じていることや活動後に行っていることを尋ね た。またそれらの経験が DA/DH活動者の精神的健 康に与える影響について検討した。

本研究の結果, DA/DH活動者は, 活動前に現場の 状況が気になったり，患者の状態がわからないなど， 活動現場の状況に注目し, 活動現場の状況が自分の 能力を超えているかもしれないと感じる一方で, 使 命感を感じていた。またDA/DH活動者は, 活動中に 使命感や高揚, 達成感などの肯定的な感情と, 焦り や恐怖などの否定的な感情を感じていた。以上の結 果から, DA/DH活動者は，使命感を感じながらも， 現場や患者の状況がわからず，自分の能力を超えて いるかもしれないという不安を感じていることが明 らかになった。 DA/DH活動者が活動現場に到着する までに，少しでも多くの現場情報を得ることができ 
Table 2. GHQ scores and responses to item by respondent type.

\begin{tabular}{|c|c|c|c|c|c|}
\hline & & $\mathrm{n}$ & mean & SD & \\
\hline \multirow[t]{5}{*}{ Frequency of operation } & 11 times or more a month & 14 & 1.14 & 1.51 & $\mathrm{~F}(4,271)=2.17$ \\
\hline & 6-10 times a month & 53 & 2.89 & 2.94 & \\
\hline & $1-5$ times a month & 167 & 2.07 & 2.42 & \\
\hline & A few times in 6 months & 39 & 2.54 & 2.83 & \\
\hline & Once, or less in a year & 3 & 4.00 & 2.65 & \\
\hline \multirow[t]{3}{*}{ Operation style } & Doctor ambulance & 119 & 2.41 & 2.75 & $F(2.276)=0.85$ \\
\hline & Doctor helicopter & 122 & 2.25 & 2.56 & \\
\hline & Both & 38 & 1.79 & 1.95 & \\
\hline \multirow[t]{2}{*}{ Gender } & Male & 242 & 2.16 & 2.54 & $\mathrm{t}(276)=1.54$ \\
\hline & Female & 36 & 2.86 & 2.74 & \\
\hline \multirow[t]{4}{*}{ Age } & In the $20 \mathrm{~s}$ & 47 & 2.19 & 2.67 & $F(3.275)=0.17$ \\
\hline & In the $30 \mathrm{~s}$ & 134 & 2.37 & 2.63 & \\
\hline & In the $40 \mathrm{~s}$ & 69 & 2.16 & 2.49 & \\
\hline & 50 or more & 29 & 2.07 & 2.40 & \\
\hline \multirow[t]{5}{*}{ Position } & Physician-in training (first, second year) & 9 & 3.22 & 3.23 & $F(4,274)=0.85$ \\
\hline & Physician-in training (third, fourth year) & 47 & 1.98 & 2.42 & \\
\hline & Rotated from another departments & 4 & 0.75 & 0.50 & \\
\hline & Staff & 213 & 2.29 & 2.60 & \\
\hline & Others & 6 & 2.67 & 2.25 & \\
\hline \multirow[t]{5}{*}{ Medical experience } & $0-5$ years & 59 & 2.41 & 2.65 & $\mathrm{~F}(4,273)=0.09$ \\
\hline & $6-10$ years & 79 & 2.30 & 2.47 & \\
\hline & $11-15$ years & 58 & 2.21 & 2.73 & \\
\hline & $16-20$ years & 38 & 2.16 & 2.54 & \\
\hline & Within 21 years & 44 & 2.16 & 2.54 & \\
\hline \multirow[t]{5}{*}{ Experience in emergency medicine } & $0-5$ years & 119 & 2.41 & 2.57 & $F(4,274)=0.96$ \\
\hline & $6-10$ years & 70 & 2.46 & 2.83 & \\
\hline & $11-15$ years & 40 & 1.68 & 2.08 & \\
\hline & $16-20$ years & 29 & 2.31 & 2.90 & \\
\hline & Within 21 years & 21 & 1.71 & 1.90 & \\
\hline \multirow[t]{3}{*}{ Mainly taken areas } & Mainly urban areas & 87 & 2.04 & 0.32 & $F(2,275)=0.81$ \\
\hline & Mainly rural areas & 85 & 2.05 & 0.31 & \\
\hline & Both urban and rural areas & 106 & 2.10 & 0.40 & \\
\hline \multirow[t]{2}{*}{ Marital status } & Married & 199 & 1.98 & 2.36 & $\mathrm{t}(122)=2.55^{*}$ \\
\hline & Unmarried & 80 & 2.93 & 2.93 & \\
\hline \multirow[t]{2}{*}{ Children } & Yes & 162 & 2.02 & 2.43 & $\mathrm{t}(277)=1.81$ \\
\hline & No & 117 & 2.58 & 2.73 & \\
\hline
\end{tabular}

$* \mathrm{p}<0.05$

Data with missing values were excluded from the analysis.

るようにシステムを改善することや，ともに現場で 活動すると予想される警察官や救急隊員などの協働 者と情報を共有する仕組みが必要であろう。

また活動後に DA/DH活動者は，ともに出場した人
や，同僚と活動内容を話したり報告していた。とも に出場し同様の経験をした人や，DA/DH活動をする 同立場におかれた同僚と話をすることによって，経 験の内容や，その時の感情などを共有していること 
Table 3. Chi-square test ant responses to item by GHQ types.

\begin{tabular}{|c|c|c|c|c|c|}
\hline & \multicolumn{2}{|c|}{ Low risks } & \multicolumn{2}{|c|}{ High risks } & \multirow{2}{*}{$\chi^{2}$} \\
\hline & $\mathrm{n}$ & $\%$ & $\mathrm{n}$ & $\%$ & \\
\hline \multicolumn{6}{|l|}{ Pre-operation feelings } \\
\hline 1 Unsure of conditions of the patient & 107 & $(50.7)$ & 40 & $(58.8)$ & 1.36 \\
\hline 2 Anxiety about ability to deal with the conditions & 96 & $(45.5)$ & 50 & $(73.5)$ & $16.20 * *$ \\
\hline 3 Unsure of surrounding conditions & 75 & $(35.5)$ & 28 & $(41.2)$ & 0.70 \\
\hline 4 Fear of danger & 82 & $(38.9)$ & 35 & $(51.5)$ & 3.36 \\
\hline 5 Worry about criticism & 38 & $(18.0)$ & 24 & $(35.3)$ & $8.89 *$ \\
\hline 6 Highly motivated & 81 & $(38.4)$ & 24 & $(35.3)$ & 0.21 \\
\hline 7 Sense of duty & 94 & $(44.5)$ & 29 & $(42.6)$ & 0.76 \\
\hline 8 Worry about situation of the scene & 123 & $(58.3)$ & 39 & $(57.4)$ & 0.02 \\
\hline 9 Others & 9 & $(4.3)$ & 4 & $(5.9)$ & 0.30 \\
\hline 10 Feel nothing & 6 & $(2.8)$ & 1 & $(1.5)$ & 0.40 \\
\hline \multicolumn{6}{|l|}{ Feelings experienced during the operation } \\
\hline 1 Sense of achievement & 71 & $(34.0)$ & 22 & $(32.4)$ & 0.06 \\
\hline 2 Excitement & 54 & $(25.8)$ & 24 & $(35.3)$ & 2.27 \\
\hline 3 Elation & 76 & $(36.4)$ & 25 & $(36.8)$ & 0.00 \\
\hline 4 Sense of duty & 120 & $(57.4)$ & 48 & $(70.6)$ & 3.73 \\
\hline 5 Sense of helplessness & 19 & $(9.1)$ & 19 & $(27.9)$ & $15.40 * *$ \\
\hline 6 Anger & 8 & $(3.8)$ & 2 & (2.9) & 0.12 \\
\hline 7 Fear & 28 & $(13.4)$ & 18 & $(26.5)$ & $6.33 *$ \\
\hline 8 Surprise & 23 & $(11.0)$ & 10 & $(14.7)$ & 0.67 \\
\hline 9 Distrust & 6 & $(2.9)$ & 3 & (4.4) & 0.39 \\
\hline 10 Discomposure & 20 & $(9.6)$ & 20 & (29.4) & $16.35 * *$ \\
\hline 11 Sense of guilt & 2 & $(1.0)$ & 6 & $(8.8)$ & $11.32 * *$ \\
\hline 12 Sense of urgency & 44 & $(21.1)$ & 24 & $(35.3)$ & $5.62 *$ \\
\hline 13 Others & 18 & $(8.6)$ & 3 & (4.4) & 1.29 \\
\hline 14 Feel nothing & 18 & $(8.6)$ & 4 & $(5.9)$ & 0.52 \\
\hline \multicolumn{6}{|l|}{ Post-operation activities } \\
\hline 1 Talking with people that participated in the activities about the activity content & 151 & $(71.9)$ & 53 & $(77.9)$ & 0.96 \\
\hline 2 Sharing the feelings with people that participated in the activities together & 48 & $(22.9)$ & 20 & $(29.4)$ & 1.19 \\
\hline 3 Talking or reporting the content of activity to the supervisors & 83 & $(39.5)$ & 29 & $(42.6)$ & 0.21 \\
\hline 4 Talking to colleagues about the content of activity & 133 & $(63.3)$ & 40 & $(58.8)$ & 0.44 \\
\hline 5 Changing mood & 24 & $(11.4)$ & 15 & $(22.1)$ & $4.81 *$ \\
\hline 6 Others & 9 & $(4.3)$ & 2 & (2.9) & 0.24 \\
\hline 7 Doing nothing & 21 & $(10.0)$ & 4 & (5.9) & 1.06 \\
\hline
\end{tabular}

$* \mathrm{p}<0.05, * * \mathrm{p}<0.01$

が予想される。活動後に気分転換をするといった回 答もみられたことから, 活動による疲れなどを解消 するための行動が個別にも行われていると考えられ る。

DA/DH活動者の精神的健康については, 配偶者 がいる者よりもいない者の方が精神的不健康が有意 に高かった。前述のように, DA/DH活動者が活動 後に他者と話をしたり, 気分転換をするなどの行動
をしていることを踏まえると, 配偶者と話をして感 情を表出することや, 気分転換となる活動をするこ とも, DA/DH活動者の精神的健康の維持や回復に 効果的であると推定される。

また DA/DH活動者の $24.4 \%$ が，精神的不健康の 危険性が高い高リスク群であることが示された。一 般成人を対象とした調査 ${ }^{5}$ において, 本研究で用い た基準と一致する高リスク群（4点以上）が，全体 
の $58.4 \%$ あるることを踏まえると，DA/DH活動者 では高リスク群に該当する割合が低いものの, 全体 の 4 分の 1 は精神的に不健康であった。精神的不健 康の高リスク群は, 活動前に活動現場の状況が自分 の能力を超えているかもしれない, 批判を受けるか もしれないといった不安を感じていた。活動中に は, 無力感や怒り, 動摇, 罪悪感, 焦りなどの否定 的な感情を感じていた。予想できない活動現場への 出場に対して, 自身の能力やその後の周囲の評価等 に不安を抱き, 否定的な感情を感じている者ほど, 精神的不健康の危険性が高くなっていると考えられ る。また精神的不健康の高リスク群は, 活動後に気 分転換をする者が有意に多く, 活動前や活動中に感 じた否定的な感情を解消しょうと試みていると予想 される。

以上より, DA/DH活動者の一部には, DA/DH活動 によって心的負担を感じ, 精神的健康を維持するこ とができず，精神的不健康の高リスク群に陥ってい る者が存在していることが明らかになった。ただし 本研究において採用した $\mathrm{GHQ}$ の得点は DA/DH 活動 前後や, 活動以外の影響を受けて得点が変化する可 能性もある。加えて, 本研究ではDA/DH活動者のみ を対象としており, 活動を行わない医師との得点比 較を行っていない。DA/DH活動と精神的健康との関 連については，今後さらなる検討が必要である。

最後に，DA/DH活動者を対象とした活動支援シ ステムのあり方について議論する。本研究の結果を 踏まえると，DA/DH活動者自身が活動に伴う心的 負担を理解する必要がある。具体的な方法として は，事前教育，訓練体制を整える必要がある。

事前教育では，活動に伴う心的負担に着目する必 要がある。金ら あ) は災害時の援助者の事前対策とし て, 援助者に生じ得るストレスについて, それが恥 じるべきことではなく，適切に対処すべきであるこ とを教育しておくことが有効であるとしている。活 動現場の状況が自分の能力を超えているかもしれな いといった不安や, 活動中の恐怖などの否定的感情 はDA/DH活動者の多くが感じていることであり, 誰
もが活動によって心的負担を感じることを理解して おく必要がある。なお, 自分の能力を超えているか もしれないといった不安は，救急医療に携わってい る年数が 5 年以下の医師が感じており, 経験の浅い 医師にはとくに注意する必要がある。活動に伴う心 的負担によって, 精神的不健康の高リスク群に陥る 可能性があることも教育する必要があるであろう。

また活動中の否定的感情を未然に防ぐための事前 の訓練も効果的であろう。重村ら ${ }^{7)}$ は, 遺体関連業 務をする救援者の心的負担を軽減させるために，業 務前に可能な限り事前訓練を行い，活動で予測され る事態や, 活動に伴う不快感, 感情移入しやすい遺 体の特徵などを知り, 予想される様々な事態を想定 させる「心の準備」が必要であると指摘している。 DA/DH活動現場は予測困難であるが, 活動者が事 前に心の準備をすることで, 活動中の様々な否定的 感情に対応できると期待される。実際の活動現場を 想定し, 訓練することによって, 活動中の動摇や焦 りなどを防ぐことができる可能性もある。また金 ら 6) は災害時の援助者の事前対策として, 災害が生 じた場合の情景や死傷者の光景などのスライドを見 たり，援助活動における住民とのやりとりに関する ロールプレイなどをあげており，このような内容は DA/DH活動者の訓練にも応用することができるで あろう。

なお DA/DH活動者が心的負担を感じた際の効果 的な対処方法については, 今後検討する必要があ る。本研究の結果, 精神的不健康の高リスク群は, 活動後に気分転換をしており, 活動前や活動中に感 じた否定的な感情を解消しょうと試みているが，十 分な効果が得られていなかった。したがって, 本研 究では効果的な対処方法を明らかにすることができ なかった。ただし本研究の結果, DA/DH活動者は 同立場におかれた同僚と話をすることによって，経 験の内容や, その時の感情などを共有していること が明らかになった。東京消防庁活動安全課ら ${ }^{8)}$ によ れば，東京消防庁では消防職員を対象とした惨事入 トレス対策として，デフュージングと呼ばれるグ 
ループミーティングなどを実施している。とくに反 省会等を目的とした形式的ではなく, 普段の会話の ような雲囲気で実施することが望ましいことが指摘 されている。DA/DH活動者が心的負担を感じた際 の効果的な対処方法として, 活動者自身と周囲の同 僚が会話する雲囲気を促したり，心理的なケアを行 う組織的な取り組みが必要であると考えられる。

\section{結 語}

本研究の結果，DA/DH 活動者は，使命感を感じ 活動している一方で, 不安を感じ活動しており, 活 動者の中には, 精神的不健康の高リスク群に陥って いる者も存在することが明らかになった。 DA/DH 活動者自身が，活動による心的負担を十分に理解す ることが必要である。事前教育や訓練の実施と組織 的な取り組みが可能な活動支援システムの構築が期 待される。

本研究は，2009年度三井住友海上福祉財団（研究代 表者：吉野美緒）および救急振興財団（研究代表者： 増野智彦）の助成を受けた。また本研究を実施するに あたり,ご指導いただいた重村朋子先生 (日本医科大学) に深く御礼申し上げます。

\section{なお本研究に開示すべきCOI はない。}

\section{文献}

1) 荻野隆光: プレホスピタルムック 3 エアレスキュー・ド クターカー. 益子邦洋編: ドクターヘリシステム. 永井書 店, 2007, p23-35.

2) 成田健一: General Health Questionnaire 12 項目版の多次元 性を探る。東京学芸大学紀要第 1 部門 (教育科学). 2001; 52: 115-27.

3) Goldberg DP: The Detection of psychiatric illness by questionnaire. London, Oxford University Press, 1972.

4) 中川泰涁, 大坊郁夫: 日本語版 GHQ 精神健康調査票 <手 引き>. 1985.

5) 福岡欣治, 安藤清志, 松井豊: 無作為抽出サンプルによる General Health Questionnaire12 項目版の検討 東洋大学 21 世紀ヒューマン・インタラクション・リサーチ・センター 研究年報, 2005, p73-81.

6) 金吉晴, 安部幸弘, 荒木均, 他: 平成 13 年度厚生科学研究 費補助金 (厚生科学特別研究事業) 災害時地域精神保健 医療活動ガイドライン http://www.ncnp.go.jp/nimh/pdf/ saigai_guideline.pdf Accessed January 29, 2014

7) 重村淳, 武井英里子, 徳野慎一, 他: 遺体関連業務におけ る災害救援者の心理的反応と対処方法の原則. 防衛衛生. 2008, p163-8.

8) 東京消防庁活動安全課, 松井豊, 畑中美穂: 惨事ストレス 対策に関する調査検証.火災. 2007; 57: 18-24. 


\title{
ABSTRACT \\ The relation between psychological conditions and mental health on the physicians working in prehospital care
}

\author{
Miho Ichimura ${ }^{1}$, Haruki Takada $^{2}$, Tomohiko Masuno $^{3}$, Mio Yoshino $^{4}$ \\ Eri Inamoto ${ }^{5}$, Yutaka Matsui ${ }^{2}$, Hiroyuki Yokota ${ }^{3}$ \\ ${ }^{1}$ Faculty of Human Sciences, Mejiro University \\ ${ }^{2}$ Graduate School of Comprehensive Human Sciences, University of Tsukuba \\ ${ }^{3}$ Department of Emergency and Critical Care Medicine, Nippon Medical School \\ ${ }^{4}$ Department of Pediatrics, Nippon Medical School \\ ${ }^{5}$ Nippon Medical School Tama Nagayama Hospital
}

Psychological conditions of physicians before, during, and after doctor ambulance (DA) and doctor helicopter (DH) operations were investigated. A questionnaire survey was conducted with physicians involved in DA/DH operations. The number of valid responses was 283 (a valid response rate of 73\%). The survey inquired physicians about their feelings and actions before, during, and after operations. Furthermore, their mental health was measured using the General Health Questionnaire (GHQ). Results indicated that physicians had a sense of duty for their job. However, physicians also felt anxious before and during operations, because they did not have sufficient information and were unsure of their ability to deal with the situation and the patient. After the operation, they shared their experiences and feelings with their colleagues. The GHQ indicated that $24.4 \%$ of the participants were at high risks of mental health problems. Those at high risks felt anxiety before the operation, because the situation might go beyond their abilities, and because they might get criticized. During the operation, they experienced negative feelings, such as anger and a sense of helplessness. It was indicated that some physicians involved in DA/DH operations felt a mental burden and were in an unhealthy mental conditions. Based on the above results, it is suggested that development of organized support systems are needed for physicians in DA/DH operations, including pre-education and training focusing on their anxieties and fears during operations, as well as measures to deal with them.

(JJAAM. 2014; 25: 141-51)

Keywords: doctor ambulance, doctor helicopter, psychological maladjustment, introduction training

Received on May 8, 2013 (13-042) 